\title{
Determinants of Common Bean (Phaseolus Vulagris L.) Marketed Surplus Among Smallholder Farmers in Humbo and Damot Gale Woredas, Southern Ethiopia
}

\author{
Besufekad Belayneh (Corresponding author) \\ School of Environment, Gender and Development Studies \\ Hawassa University, P.O.Box 05.Hawassa, Ethiopia \\ E-mail: belayneh.besufekad@gmail.com
}

Tewodros Tefera

School of Environment, Gender and Development Studies

Hawassa University, P.O.Box 05.Hawassa, Ethiopia

Thomas Lemma

School of Environment, Gender and Development Studies

Hawassa University, P.O.Box 05.Hawassa, Ethiopia

Received: August 24, 2018 Accepted: September 18, 2018 Published: November 13, 2018

doi:10.5296/jfi.v2i1.13898 URL: http://dx.doi.org/10.5296/ jfi.v2i1.13898

\begin{abstract}
This research was aimed to study the common bean (Phaseolus vulagris L.) marketed surplus among smallholder farmers in the Humbo and Damot Gale Woredas. A multi-stage sampling technique was used in order to determine the sample respondents. By using simple random sampling technique four sample Kebeles were selected. Cross sectional data were collected from 182 farm households who produced common bean in 2016 production season. Primary data were collected from sample households using structured questionnaire. Descriptive statistics and econometric model were employed to analyze the data. To identify determinants of marketed surplus of common bean, Ordinary Least Square (OLS) model was employed.
\end{abstract}




\section{Macrothink}

The study suggest interventions such as intensification strategies which increase yields through proper management and use of inputs, rural infrastructure improvement increases the likelihood of market orientation and marketed surplus of common bean.

Keywords: Common bean, marketed surplus, household

\section{Introduction}

Pulses are important components of crop production and cash crop in Ethiopia and contribute considerably to attain food and nutritional security (Tewodros, 2013). Pulse crops occupy about $13 \%$ of croplands in Ethiopia and are the second most important elements in the national diet (CSA, 2015). In Ethiopia, Common bean (Phaseolus Vulagris L.) is grown predominantly under smallholder producers as an important food crop and source of cash (Shiferaw et al., 2007).The Southern Nation, Nationalities and Peoples Region (SNNPR) production of common bean accounts $15 \%$ the total common bean production in the country (Rashid et al.,2010). Common bean productions of Humbo and Damot Gale Woredas in 2016 production season were 7.812 MT and 6.799 MT respectively, among this legally marketed amount of common bean crops were 2.626 MT and 3.086 MT respectively (Humbo WoANR, 2017; Damot Gale WoANR, 2017).

The study Woredas have sufficient potential and environmental settings for production of common bean. Some studies investigated the major constraints of common bean crop production in the study sites. Tewodros (2013) reported that land shortage, low soil fertility and disease on common bean crop were the major constraint limiting common bean production in Damot Gale Woreda. On the other hand, the common bean market of the study areas had grown substantially in recent years, although the current market is still under developed (Rashid et al., 2010). A study in the Rift Valley of Ethiopia including Humbo and Damot Gale Woredas found that limited access to credit, poor market linkage and price volatility were also problems of common bean crop producers (Frehiwot, 2010). However, in the aforementioned study the common bean crop marketing is not well explored.

The available literature on pulses dwells on the performance of the existing common bean cultivars (Legesse et al., 2006) and analysis of common bean value chain in Southern Ethiopia (Tewodros, 2013). The available information on determinants of marketed surplus of common bean is not sufficient. Moreover, the recently of common bean in SNNPR also deserve new studies. Hence, this study designed to address the research gap to provide valuable information for practitioners, researchers, policy makers and producers. The study analyzed the determinants of common bean marketed surplus in the Humbo and Damot Gale Woredas of SNNPR.

\section{Methodology}

\subsection{Description of the Study Area}

The study was conducted in Southern Nation, Nationalities and Peoples Region (SNNPR), Humbo and Damot Gale Woredas of Wolayta Zone. Humbo is one of the Woredas in Wolayta zone. The administrative center of Humbo is Tebela. The Woreda is located in $6^{0} 43^{\prime} \mathrm{N}$ 


\section{Macrothink}

latitudes and $37^{\circ} 45^{\prime} \mathrm{E}$ longitudes and 1100 to 2300 m.a.s.l. The agro-climate zone of the area comprises Woina-dega (30\%) and kola (70\%) (HumboWoANR, 2017). Based on the 2007 census conducted by the CSA, this Woreda has a total population of 125,441 , of whom 63,017 are men and 62,424 women; about 6,247 or $4.98 \%$ of its population are urban dwellers.

Damot Gale is located in $7{ }^{0} 58^{\prime} \mathrm{N}$ latitudes and $37{ }^{0} 52^{\prime} \mathrm{E}$ longitudes and altitude of 1501 to 2050 m.a.s.l. The administrative center of Damot Gale is Boditi. The Woreda agro-climate zone of the area is characterized by Woina-dega (Damot Gale WoANR, 2017). Based on the 2007 Census conducted by the CSA, the Woreda has a total population of 151,079, of whom 74,227 are men and 76,852 women; and about 24,133 or $15.97 \%$ of its population are urban dwellers.

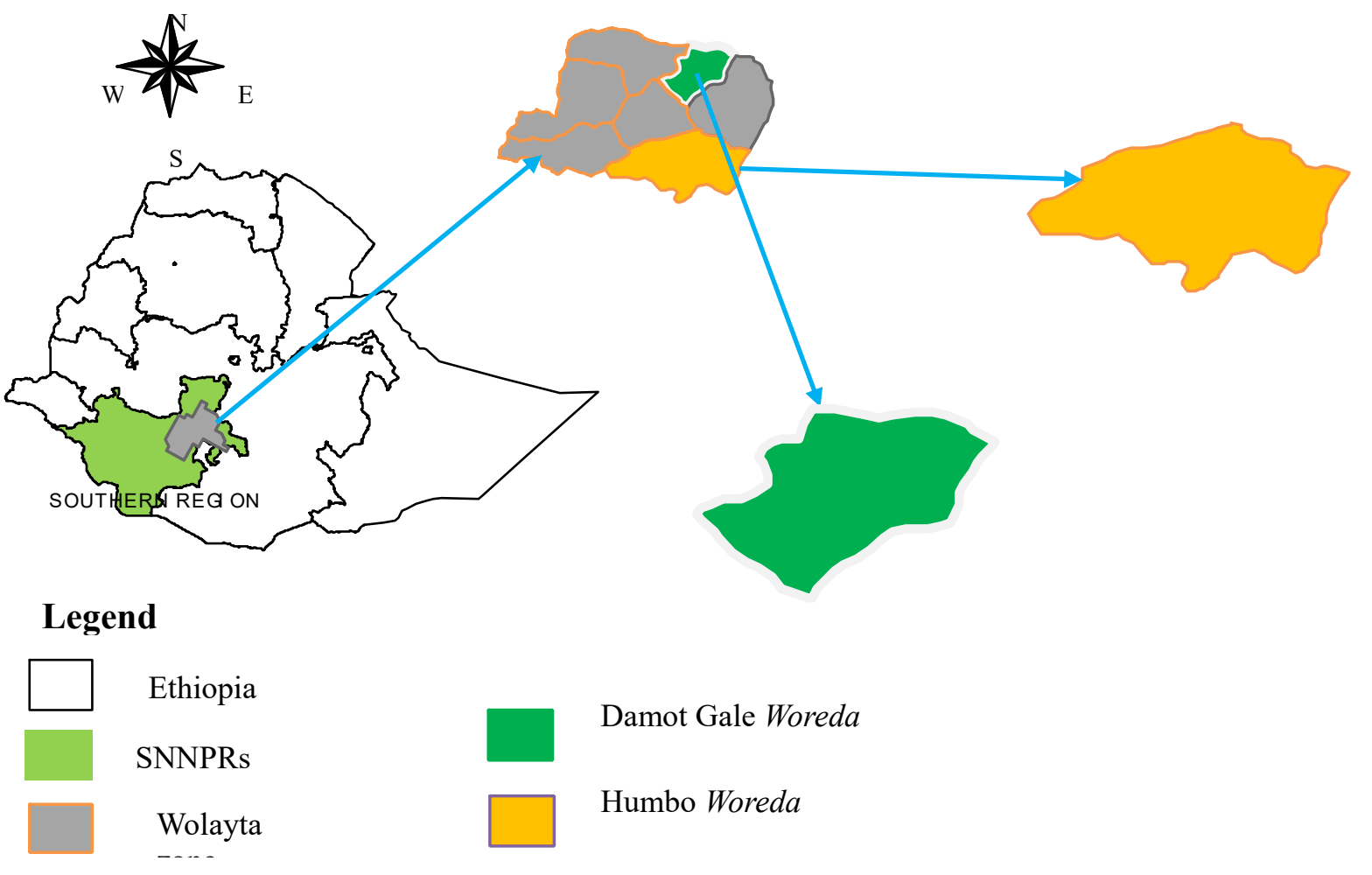

Figure 1. Geographical map of the study areas

\subsection{Research Design}

\subsubsection{Data Types, Sources and Methods of data Collection}

The study used both primary and secondary sources of data, which is qualitative and quantitative in nature. The primary data were collected using questionnaire. Secondary data were obtained from various sources such as reports of Bureau of Agriculture and Natural Resources at different levels, CSA, NGOs, previous research findings, journal articles, e-books and other published and unpublished materials which are found to be relevant to the study. 


\section{Macrothink}

To generate the necessary data from the primary sources, different procedural approaches such as face to face interview with sample respondent households were used. Most of research data were collected through questionnaires by means of household survey. The farm household survey data collected by using enumerators since most of farm households was not able to read and write. A total of 6 enumerators from Woreda office of agriculture and natural resources who speak the local language were selected and trained on the method of administering the interview schedule in general and on the content of the questionnaire in particular. The enumerators had a qualification of a minimum of college diploma. Before administrating the survey, questionnaire pretesting was conducted by enumerators to test the contents of the questionnaire, to measure how long it takes to fill a questionnaire and validate interviewing approaches. The pretesting was conducted in a Gacheno Kebele administrative. Then, the questionnaire was revised and content, which was unclear, was modified and removed. The field data collection were took 15 days, and all efforts were exerted to supervise on field level to check and correct gaps.

\subsubsection{Sampling Technique and Sample Size Determination}

\subsubsection{Sampling Technique}

In this study, multi-stage sampling technique was used. In the first stage, all Kebeles of the two Woredas (Damot Gale and Humbo Woredas) were stratified into common bean producers and non-producers. From the 65 Kebeles about 40 Kebeles were found to be common bean producers. Secondly, by using simple random sampling techniques, 4 sample Kebeles out of 40 pulse crops producer Kebeles were selected. Following the kebele selection, households were stratified in to producers and non-producers of common bean crops. Finally, common bean producing sample households were selected from common bean producing stratum using systematic random sampling technique.

\subsubsection{Sample Size Determination}

An important decision to be taken while adopting a sampling technique is about the size of the sample. Hence, the sample size of the study was determined based on the scientific formula that designed to find out the appropriate size of the survey research. In the study, the Khotari (2004), sample size determination formula used in order to decide the size of sample population:

$$
n=\frac{Z^{2} * N * p^{*} q}{e^{2}(N-1)+Z^{2} * p^{*} q}
$$

Therefore, by using the formula using $Z=1.96$ to $95 \%, p=0.5, q=1-p$ and $e^{2}=0.07, N=$ 2,616 values and the sample size calculated $n=182$ (165 male and 17 female) which is the necessary sample size of the study.

Where: $\mathbf{N}=$ total households, $\mathrm{n}=$ size of the sample, $\mathrm{Z}=$ standard variation at a given confidence level, $\mathrm{P}=$ proportion of successes, $\mathrm{q}=$ proportion of failures, $\mathrm{e}^{2=}$ acceptable error. 


\section{Macrothink}

Table 1. Sample Size and Sample Distribution by Kebeles

\begin{tabular}{lll}
\hline Sample Kebeles & Common bean Crops & Selected Size of ample \\
& Producing households & \\
\hline Gututo Larena & 550 & 39 \\
Abala Sipa & 823 & 59 \\
Taba & 776 & 48 \\
Gacheno & 467 & 36 \\
Total & 2,616 & 182 \\
\hline
\end{tabular}

Source: Own computation based on data from WoANR (2017).

\subsection{Methods of Data Analysis}

\subsubsection{Ordinary Least Square Model (OLS)}

OLS regression model was used to analyze determinants of marketed surplus of common bean in Humbo and Damot Gale Woredas. The reason for using this model was that all sample farmers who produced common bean were suppliers to the market in 2016 production season. The OLS regression model was specified as $\mathrm{Y}=\mathrm{f}$ (Farm size, Age of household head, Sex of household head, Education status, Households size, Farming experience, Access to credit, Market price of output, Livestock holding, Membership to cooperatives, Extension contact, Distance to the market, Off- farm income activities, Access to market information, Input used). The estimated coefficients indicate the amount of change in the dependent variable due to a unit change in the independent variable keeping other factors constant.

In matrix form, the supply function can be specified as:

$\mathrm{Y}=\beta \mathrm{X}+\mathrm{U}$

Where: $\mathrm{Y}=$ the volume of common bean supplied to the market in Kilogram

$$
\begin{aligned}
& \beta=\text { a vector of estimated coefficient of the explanatory variables } \\
& X=\text { a vector of explanatory variables, } U=\text { Disturbance term }
\end{aligned}
$$

Before fitting the independent variables in the OLS regression model, multicolinearity, heteroscedasticity and omitted variables test were performed. Multicollinearity was tested using variance inflation factor (VIF). To address heteroscedasticity and omitted variables, Breusch-Pagan and ovtest were conducted using STATA software version 12.

\section{Results and Discussion}

\subsection{Socio-Economic and Demographic Characteristics of Respondents}

The average age and family size of the sample households were 40.1 years and 6 persons, respectively. The household respondents' average experience in farming was 16.4 years. On 


\section{Macrothink}

Journal of Food Industry

ISSN 1948-545X

2018, Vol. 2, No. 1

average common bean producer households own about 0.31 hectares of land for common bean production and owned 4.24 livestock measured in TLU. The sample households located 6.02 kilometer away from the nearest market place (Table 2).

The households on average obtained an annual gross off-farm income of 1080.5 Birr. The lagged price of common bean per quintal was 957.9 Birr (Table 2). The majority of the respondent households were applied improved variety $(95.05 \%)$, access to credit $(79.67 \%)$, and member of cooperative $(80.22 \%)$. Overwhelming majority $(95.05 \%)$ of respondents attained formal education (Table 2).

Table 2. Socio-economic and demographic characteristics of common bean marketed surplus

\begin{tabular}{llll}
\hline Variables & Variable Description & Mean & Std.dev. \\
\hline Age & Number of Years & 40.1 & 7.7 \\
Household size & Number of individuals of family & 6 & 1.7 \\
Farm experience & Number of years & 16.4 & 8.8 \\
Cultivated area & Measured in Hectares & 0.31 & 0.07 \\
Distance nearest market & Measured in Kilometer & 6.02 & 3.04 \\
Lagged Market price & Measured in Birr & 957.9 & 609.08 \\
Off-farm activity income & Measured in Birr & 1080.5 & 2045.04 \\
Livestock holding & Measured in Tropical livestock unit & 4.2 & 2.4 \\
& & $\%$ & \\
Sex (male, \%) & 1=male, $0=$ female & 85.71 & \\
Improved Seed variety (\%) & 1=yes, $0=$ No & 95.05 & \\
Access to credit (\%) & 1=yes, 0=No & 79.67 & \\
Cooperative membership (\%) & 1=yes, 0=No & 80.22 & \\
Education status (\%) & 1= formal education, 0=No & 95.05 & \\
\hline
\end{tabular}

Note. ${ }^{* * *}, * *$ and $*$ represents significance at $1 \%, 5 \%$ and $10 \%$ probability levels, respectively.

Source: Own computation of survey data, 2016/17.

\subsection{Determinants of Common Bean Marketed Surplus}

The overall goodness of fit of the regression model measured by the coefficient of determination $\left(R^{2}\right)$ and $F$ value was statistically significant at $1 \%$. The $R^{2}$ value of 0.6965 indicate that the independent variables included in the regression explain $69.6 \%$ of the variations determine the common bean marketed surplus. The OLS regression model used to 
identify determinant factors influencing the marketed surplus of common bean indicate that out of 13 explanatory variables four were found to affect the marketed surplus of common bean significantly. These were cultivated area, seed variety and distance to nearest market and livestock holding (TLU).

\subsection{Cultivated Area}

The common bean cultivated area was found to influence marketed surplus of common bean positively at $1 \%$ significance level. The finding implies that the larger the cultivated land allocated to common bean production the larger the amount produce and thereby raising the amount produce available for sale. Thus, a hectare increases in cultivated area under common bean production increase the amount of common bean sold by 297 kilograms. The result is consistent with the findings of Shewaye et al., (2016) it was found that the larger the cultivated land size allocated to haricot bean production the larger the quantity produce and thereby increasing the quantity produce available for sale in Misrak Badawacho District of Southern Ethiopia.

\subsection{Improved Seed Variety}

As expected improved seed variety was found to affect marketed surplus of common bean positively and significantly at 5\% significance level. This implies that, households who have access to improved seed of common bean was more likely to supply large amount of common bean to the market. The result is consistent with the findings of Yaynabeba and Tewodros (2013). They reported that the haricot bean producers who had ease of access to input supply like improved seed varieties participated in the market more by increasing amount of haricot bean marketable surplus compared to those who did not have access to improved variety.

\subsection{Distance to the Nearest Market}

Distance to the market negatively and significantly influences the marketed surplus of common bean. This means that as common bean producers residence home distance to the market increases, the amount of common bean sold by smallholder farmers' decrease. It was significant and negatively affects the level of marketed surplus at $1 \%$. The possible explanation for this is that as distance from the market increases, transport costs also increase and this discourages resource constrained smallholder farmers from selling high volumes to the market. The result showed that a kilometer increases in distance to the nearest market decrease the marketed surplus of common bean by 20 kilograms, keeping other factors held constant. The result is consistent with the findings of Byron et al., (2012) it was found that farmers located in villages with large distance to market and poor road quality between the village and the market place sold fewer potatoes.

\section{6 Livestock Holding}

This variable affected common bean marketed surplus significantly and positively at $5 \%$ level. Livestock holding (TLU) is a proxy for wealth under Ethiopian farmers' condition and sometimes it considered as an asset. The feasible explanation is that resource endowed households have more TLU which they can use for traction and transportation, a development 
which reduces production and market related transaction costs. The resource-endowed households are likely to have finances from which they are able to hire labor, purchase inoculants, and buy improved seed varieties and thus can produce common bean on larger portions of land compared to the resource constrained smallholder farmers. The result indicated that a unit increase in number of livestock (TLU) owned by the households increases marketed surplus of common bean by 15 kilogram per year. Study by Nuri et al., (2016) on kocho market participation suggests that an increase in the value of livestock owned leads to an increase in enset sale.

Table 3. OLS results for determinants of marketed surplus of common bean

\begin{tabular}{llll}
\hline Variables & Coefficient & Robust Standard error & t value \\
\hline Cons. & 0.7978566 & +4.171648 & 0.19 \\
Age & -0.0210939 & -0.0168213 & -1.25 \\
Sex of HH & 0.4201155 & +0.3355532 & 1.25 \\
Education status & -0.0454843 & +0.0362854 & -1.25 \\
Family size & 0.0774139 & +0.0542735 & 1.43 \\
Farm experience & -0.0071576 & -0.0139987 & 0.51 \\
Cultivated area & $2.96793^{* * *}$ & +0.52049 & 5.70 \\
Seed variety & $0.5157296^{* *}$ & +0.1654559 & 3.12 \\
Sold price & -0.0088445 & +0.5988572 & 0.01 \\
Distance nearest market & $-0.205493^{* * *}$ & -0.0492016 & 4.18 \\
Access to credit & -0.3589086 & +0.2505723 & -1.50 \\
Cooperative membership & 0.0526126 & +0.2776531 & 0.19 \\
Off-farm activity income & 0.0081152 & +0.0124862 & 0.65 \\
Livestock holding (TLU) & $0.1457465^{* *}$ & +0.0607016 & 2.41 \\
\hline
\end{tabular}

Number of obs $=182, F(13,168)=8.07$, Prob $>F=0.0000$, R-squared $=0.6965$,

Root MSE $=1.3444$

Note. The dependent variable is the amount of common bean marketed or sold. ** and *** represents significance at $5 \%$ and $1 \%$ probability levels, respectively.

\section{Conclusion}

Resource endowment of households such as land-holding size and livestock holding, access to seed variety and proximity to market were found influencing marketed surplus of common bean in the study area. Increasing the cultivated area was not best option as land is scarce resources and limited supply. Rather intensification strategies which increase productivity per 
unit area are an important pathway. Moreover, yield improving strategies such as proper management land and efficient application of inputs increases productivity and thereby the likelihood of market orientation. Improving rural infrastructure in the form of establishing all weather roads would assist farmers to supply more amount of common bean in to the market because it reduces transportation cost and it supports the integration of markets.

\section{References}

Byron, R., Cynthia, D., Richard, B., \& Mywish, M. (2012).Market participation and sale of potatoes by smallholder farmers in the central highlands of Angola. International Association of Agricultural Economists (IAAE) Triennial Conference, Foz do Iguaçu, Brazil.

Central Statistical Agency. (2015/16). Crop and Livestock Products Utilization Agricultural Sample Survey (Private Peasant Holdings, "Meher" Season) (Vol. VII Statistical Bulletin 586, Addis Ababa: 95)

Frehiwot Mulugeta.(2010). Profile of Haricot bean production, supply, demand and marketing issues in Ethiopia, Ethiopia Commodity Exchange Authority (ECX). Addis Ababa, 9

Khotari,C. R. (2004). Research methodology. Methods and Techniques (2nd ed., P. 418). New Delhi, India: New Age International (P) Limited.

Legesse, H., Bunyamin,T., Walelign, W., \& Hussein, M. (2017). Performance of Chickpea Cultivars in Response to Soil Zinc Application. Agronomy, 14. Retrieved from www.mdpi.com/journal/agronomy.

Nuri L., Jema H., Endrias, G., \& Lemma, Z. (2016). Determinants of Market Participation among Kocho Producers in Hadiya Zone of Southern Region of Ethiopia. Journal of Marketing and Consumer Research, 21, 41-49.

Rashid, S., Yirga, C., Behute, B., \& Lemma, S. (2010). Pulses Value Chain in Ethiopia: Constraints and opportunities for enhancing export. International Food Policy Research Institute. Washington, DC, USA.1:10

Shewaye, A., Dawit, A., \& Lemma Z. (2016). Determinants of Haricot Bean Market Participation in MisrakBadawacho District, Hadiya zone, Southern Nations Nationalities and Peoples Regional State, Ethiopia. Ethiopian Journal of Agricultural Science, 26(2), 69-8.

Shiferaw, B., \& Hailemariam, T. (2007). Structure and functioning of chickpea markets in Ethiopia: Evidence based on analyses of value chains linking smallholders and markets. International livestock research institute (ILRI), Nairobi, Kenya. 6:1-55

Tewodros, T. (2013). Market and consumer studies of pulse crops in Southern Ethiopia. Hawassa University School of Environment, Gender and Development Studies. Hawassa, Ethiopia: 59

Yaynabeba, A., \& Tewodros, T. (2013). Factors influencing market participation decision and extent of participation of haricot bean farmers in Meskan District, Ethiopia. International 


\section{Macrothink

Journal of Management and Development Studies, 2, 23-24.

\section{Copyright Disclaimer}

Copyright for this article is retained by the author(s), with first publication rights granted to the journal.

This is an open-access article distributed under the terms and conditions of the Creative Commons Attribution license (http://creativecommons.org/licenses/by/4.0/). 